\title{
PENGUMPULAN DATA KEPERAWATAN DALAM BERPIKIR KRITIS
}

\author{
Syifahanun Septiani \\ syifahanun.s@yahoo.co.id
}

\section{Latar belakang}

Berpikir kritis adalah salah satu ketrampilan yang seharusnya dimiliki agar bisa berkomunikasi dan bertahan hidup di era global dewasa ini.Salah satu manfaat dari berpikir kritis adalah membuat seseorang lebih mandiri, percaya diri dan mampu memcahkan persoalan dengan lebih bijak. Berpikir kritis memiliki dua konsep dasar yaitu delapan elemen pemikiran kritis dan Sembilan standar intelektual. Kedua konsep ini akan digunakan untuk mengukur tingkat berpikir kitis mahasiswa program studi sastra Inggris dalam membaca dan melihat keseuaiannya dengan inteligensi mereka. Kesesuaian antara kedua elemen berpikir kritis dan inteligensiakan diukur dengan menggunakan studi korelasi untuk menentukan standar pemikiran kritis yang mereka miliki. Critical Thinking (CT) tes dan Intelligence Quotient (1Q) tes akan digunakan untuk mengukur dua variable pemikiran kritis dan inteligensi. 1Q tes tidak hanya mengukur inteligensi mahasiswa melainkan juga untuk mengetahui kemampuan verbal dan perilaku mahasiswa. Disamping itu, standar pemikiran verbal, pernikiran kuantitatif, pemikiran abstrak dan ingatan jangka pendekjuga akan diketahui dari penyelenggaraan tes IQ. Dengan mengetahui kesesuaian antara tingkat pemikiran kritis dan usia mental mereka, hasil dari penelitian ini diharapkan bermanfaat untuk mengembangkan kemampuan kritis para mahasiswa selain juga bermanfaat bagi para dosen untuk memberikan strategi pembelajaran berbasis pemikiran kritis mahasiswa.

Proses keperawatan merupakan sebuah pendekatan keperawatan yang professional yang dilakukan oleh seorang perawat dengan cara mengindentifikasi, mendiagnosis, dan mengatasi respons manusia terhadap kesehatan dan penyakitnya. Tujuan yaitu agar seorang perawat mampu berpandangan lebih luas dalam mengambil kesimpulan ataupun mengambil keputusan yang terkait kesehatan klien. Metode yang digunakan yaitu dengan metode kualitatif yaitu mengummpulkan sebanyak - banyaknya data dengan literature review ini dengan menganalisis yang berfokus pada Pendekatan Berpikir Kritis pada pengkajian Proses Keperawatan. Hasil yang didapatkan yaitu, pemikiran kritis dalam pengkajian membuat perawat mengerti sepenuhnya masalah klien, mempertimbangkan besarnya masalah secara hati-hati, dan menemukan keterkaitan antar beberapa masalah. pembahasannya pengkajian merupakan merupakan tahap awal dari proses keperawatan yang terrdiri dari pengumpulan data, klasifikasi data, validasi data, dan perumusan masalah.

Kata Kunci : Berpikir kritis, proses kepewatan, pengumpulan data 


\section{Metode}

Artikel ilmiah ini menggunakan metode membaca dan menganalisa, kajian dari beberapa referensi seperti, jurnal, buku dan e-book. dan juga membandingkan beberapa jurnal yang berhubungan dengan kemampuan perawat dalam memberikan Keselamatan dan kesehatan kerja. Dari analisi berbagai sumber digunakan Untuk mengetahui kemampuan perawat dalam memberikan pengumpulan data keperawatan dalam berpikir kritis.

\section{Hasil}

Kemampuan berpikir kritis sering disebut sebagai salah satu kemampuan berpikir tingkat tinggi (Peirce, 2006). Glaser menyatakan dua elemen dalam berpikir kritis yaitu memiliki keterampilan berpikir kritis dan kemauan untuk menggunakan keterampilan tersebut. Glaser menyebutkan bahwa berpikir kritis adalah sikap yang siap untuk mempertimbangkan dengan seksama masalah-masalah yang ada dalam jangkauan pengalaman seseorang atau pengetahuan tentang metode inkuiri dan bernalar yang logis dan kemampuan untuk menerapkan metode tersebut (Glaser dalam Ricketts, 2004).

Richard Paul menyebutkan bahwa berpikir kritis merupakan suatu cara berpikir yang unik dan memiliki tujuan tertentu di mana pemikir secara sistematis menetapkan kriteria dan standar intelektual dalam berpikir, dalam mengonstruksi pemikiran, mengarahkan konstruksi berpikir sesuai dengan standar tertentu, dan menilai efektivitas berpikir sesuai tujuan, kriteria, dan standar berpikir (Paul dalam Ricketts, 2004). Sementara Rudd, Baker, dan Hoover mengemukakan bahwa berpikir kritis adalah suatu pendekatan yang menggunakan nalar, memiliki tujuan tertentu, dan menggunakannya untuk memecahkan masalah atau menanggapi pertanyaan dengan bukti dan informasi yang mengarah pada solusi yang sulit dibantah.

\section{Pembahasan}

Pada saat mengumpulkan data mengenai pasien. Seorang perawat memerlukan yang pertama pengetahuan terkait seperti proses penyebab dari penyakit, pertumbuhan dan perkembangan normal, fisiologi dan psikologi normal, hasil pengkajian yang normal, promosi kesehatan yang akan diterapkan, keterampilan dalam mengkaji, dan keterampilan dalam berkomunikasi. Yang kedua perawat harus mengingat kembali pengalaman klinis sebelumnya seperti, pengalaman dalam merawat klien sebelumna, memvalidasi hasil dari pengkajian kesehatan klien, dan mengobservasikan teknik pengkajian tersebut.

Yang ketiga perawat harus menerapkam standar pemikiran dan perilaku kritis seperti, ketekunan keadilan, integritas, percaya diri, dan kreativitas. Yang terakhir adalah menggunakan standar praktik untuk membimbing seorang perawat dalam membuat pengkajian yang benar dan bermanfaat seperti, standar prantik keperawatan American Nursing Association (ANA), standar 
praktik khusus, dan standar intelektual pengukuran. Pengkajian ini merupakan langkah yang paling kritis dalam proses keperawatan. Karena apabila dalam langkah pengkajian ini tidak diselesaikan dengan cara berfokus pada klien, perawat akan kehilangan kendali terhadap langkah proses keperawatan selanjutnya. Tanpa pengkajian keperawatan yang tepat, tidak akan diagnosis keperawatan yang berfokus pada klien, dan tanpa ada diagnosis yang tepat, tidak akan ada intervensi keperawatanyang berdasarkan bukti, mandiri, dan berfokus pada klien. Pengkajian juga bukan sekedar mengisi ruang kosong dari sebuah form atau layar computer. Tetapi pengkajian memerlukan pendekatan dalam berpikir kritis.

Tahap-tahap dalam pengkajian keperawatan ini antara lain, :

1. pengumpulan data adalah pengumpulan informasi tentang klien yang dilakukan secara sistematis untuk menentuan masalah-masalah, serta kebutuhan-kebutuhan keperawatan dan kesehatan klien. Pengumpulan informasi merupakan tahap awal dalam proses keperawatan. Dari informasi yang terumpul, didapatkan data dasar tentang masalahmasalah yang dihadapi klien. Selanjutnya data dasar tersebut digunaan untuk menentukan diagnosis keperawatan, merencanakan asuhan keperawatan, serta tindaan keperawatan untuk mengatasi masalah-masalah klien. Menurut Nursalam (2002), pengumpulan data secara umum merupakan hal yang mutlak dilakukan oleh seorang perawat dalam melakukan pengkajian keperawatan. Ada dua sumber data utama, yaitu data subjektif dan data data objektif. Data Subjektif merupakan data yang berasal dari kutipan langsung dari klien atau keluarga. Informasi tersebut tidak bisa ditentukan oleh perawat, mencakup persepsi, perasaan, ide klien tentang status kesehatannya. Misalnya tentang nyeri, perasaan lemah, ketakutan, kecemasan, frustrasi, mual, perasaan malu. Contohnya laporan dari seorang pasien mengenai nyeri punggung dan rasa takut berkaitan operasi yang akan dijalananinya merupakan keluhan subjektif. Saat mengumpulkan data subjektif inilah perlu pemikiran kritis agar data yang didapatkan dapat dengan benar Data Objektif merupakan data yang didapatkan dari hasil observasi pengukuran dari status klien. Inspeksi kondisi luka, deskripsi mengenai perilaku, dan pengukuran tekanan darah adalah beberapa contoh data objektif.

Pengukuran data objektif adalah berdasarkan standar yang telah diakui, seperti celcius atau farenheit pada thermometer, centimeter pada pengukuran panjang, atau karakteristik yang telah diketahui (ansietas atau takut). Karakteristik data yang didapatkan lengkap, antara lain: data yang terkumpul harus lengkap guna membantu mengatasi masalah klien yang adekuat, untuk menghindari kesalahan, maka perawat harus berfikir secara akurat dan nyata untuk membuktikan benar tidaknya apa yang didengar, dilihat, diamati dan diukur melalui pemeriksaan ada tidaknya validasi terhadap semua data yang mungkin meragukan.

Apabila perawat merasa kurang jelas atau kurang mengerti terhadap data yang telah dikumpulkan, maka perawat harus berkonsultasi dengan perawat yang lebih mengerti, dan mencatat data yang relevan sesuai dengan masalah klien, yang merupakan data fokus terhadap 
masalah klien dan sesuai dengan situasi khusus. Metode pengumpulan data terdiri dari hasil wawancara, riwayat kesehatan, pemeriksaan fisik, serta hasil pemeriksaan laboraturium dan dignostik untuk membuat sumber data dasar pengkajian. Yang pertama wawancara merupakan bentuk percakapan yang tersusun secara sistematik antara perawat dan klien.

Tujuan dari wawancara adalah untuk memperoleh data tentang masalah kesehatan dan masalah keperawatan klien, serta untuk menjalin hubungan antara perawat dengan klien. Selain itu wawancara juga bertujuan untuk membantu klien memperoleh informasi dan berpartisipasi dalam identifikasi masalah dan tujuan keperawatan, serta membantu perawat untuk menentukan investigasi lebih lanjut selama tahap pengajian. Macam-macam wawancara yaitu: Auto anamnesa (wawancara dengan klien langsung) dan Allo anamnesa (wawancara dengan keluarga / orang terdekat). Yang kedua yaitu pemeriksaan fisik merupakan investigasi terhadap tubuh untuk menentukan status kesehatan klien. Yang melibatkan teknik inspeksi, palpasi, auskultasi, dan penciuman. Yang ketiga saat Mengobservasi perilaku klien yaitu dilakukan selama wawancara dan pemeriksaan fisik berlangsung, seorang perawat mengobservasi perilaku verbal dan nonverbal klien yang merupakan hal penting, informasi tersebut menambahkan ketajaman dari data objektif yang sudah didapatkan.

2. Klasifikasi data Merupakan mengelompokkan data yang sudah didapatkan dari pengumpulan data. Pertama yaitu sistem tubuh antara lain, sistem rangka yaitu untuk bergerak, tempat melekatnya otot, melindungi organ-organ dalam, menopang dan memberikan bentuk tubuh. Sistem otot, sistem peredaran darah, sistem pencernaan, sistem endokrin, sistem saraf, sistem pernafasan, sistem kekebalan tubuh, sistem limfatik, sistem eksresi, sistem urinaria, sistem indra, dan sistem reproduksi.

3. Validasi Data Merupakan perbandingan data dengan sumber lain untuk menentukan ke akuratan dalam suatu data. Jadi sebelum perawat menganalisis, dan merumuskan data yang sudah didapatkan, perawat harus memvaidasikan informasi tersebut terlebih dahulu guna menghindaru kesimpulan yang salah.

4. Perumusan masalah Merupakan tahap terakhir dalam pengkajian proses keperawatan yaitu dengan menyimpulkan data yang sudah dilakukan dengan wawancara, pemeriksaan fisik, dan lainnya. Yang terdiri dari actual, resiko, potensial, sindrom, dan welnes.

\section{Penutup}

a) Kesimpulan

Berpikir kritis adalah salah satu ketrampilan yang seharusnya dimiliki agar bisa berkomunikasi dan bertahan hidup di era global dewasa ini.Salah satu manfaat dari berpikir kritis adalah membuat seseorang lebih mandiri, percaya diri dan mampu memcahkan persoalan dengan lebih bijak. Berpikir kritis memiliki dua konsep dasar yaitu delapan elemen pemikiran kritis dan Sembilan standar intelektual. Yang terdiri dari pengumpulan data, klasifikasi data, validasi data, dan perumusan masalah. dalam 
pengkajian ini perawat harus mempunyai pemikiran yang kritis agar data yang didapat bisa di interpretasikan secara tepat, akurat, dan berarti.

b) Demikian atas ulasan dari makalah ini untuk memperjelas dalam pembahasan Berpikir Kritis Dalam Bidang Keperawatan. apabila ada kekeliruan atau tidak jelasnya dalam membuat makalah ini dapat menghubungi penyusun, dan apabila ada kekurangan dari materi ini diharapkan pembaca dapat membantu dalam memperbaiki makalah ini.

\section{Daftar Pustaka}

1. Rutami, \& Setiawan. (2012). Pelaksanaan Proses Pengkajian Keperawatan di Ruang Rawat Inap RSUP H. Adam Malik Medan. 1 (2), $52-54$

2. Simamora, R. H. (2008). Peran Manajer Dalam Pembinaan Etika Perawat Pelaksana Dalam Peningkatan Kualitas Pelayanan Asuhan Keperawatan. IKESMA, 4 (2).

3. arwoto, \& Wartonah. (2010). Kebutuhan Dasar Manusia dan Proses Keperawatan. Jakarta : Salemba Medika.

4. Budiono. (2016). Konsep Dasar Keperawatan. Jakarta: Kementerian Kesehatan Republik Indonesia

5. Achmadi, L. D., Pondaag, L., \& Babakal, A. (2015). Gambaran Tingkat Pengetahuan Perawat dalam Penerapan Standar Asuhan Keperawatan di Ruangan Rawat Inap Interna RSUD Datoe Bhinangkang. Jurnal Keperawtan. 3 (3), 1-3

6. Potter, A.P., \& Perry, G.A. (2010). Fundamental Keperawatan Buku 1 Edisi 7. Jakarta : Salemba Medika

7. Nursalam. (2009). Proses dan Dokumentasi Keperawatan Konsep dan Praktik. Jakarta : Salemba Medika

8. Simamora, R. H. (2009). Dokumentasi Proses Keperawatan . Jember University Press

9. Wina Sanj ay a. $(20$ 12). Str at e gi P emb e I aj ar an Berorientasi Standar Proses Pendidikan. Bandung : Kencana.

10. Kowiyah. (2012). Kemampuan Berpikir Kritis. Jurnal Pendidikan Dasar, 3(5), 175-179.

11. Perry, A. G., \& Potter, P. A. (2009). Potter and perry's fundamentals of nursing Australian

12. Kozier, B. (2012). Fundamentalsof Nursing : Concepts,Processand Practices.9th Ed. New Jersey:Pearson Education, Inc. 